\title{
Naisten työturvallisuus maatiloilla
}

\author{
Marja Kallioniemi ${ }^{*}$ \\ ${ }^{*}$ MTT Taloustutkimus, os. MTT Vihti, Vakolantie 55, 03400 Vihti, marja.kallioniemi@mtt.fi
}

MTT:ssä on meneillään "MYEL-vakuutettujen naisten työturvallisuus” -hanke, joka sisältää kirjallisuustutkimuksen, havainnointi- ja haastatteluaineiston sekä kyselyn sidosryhmille. Empiirinen aineisto on kerätty havainnoiden naisten työtä 10 maitotilalla ja haastatellen heitä. Hankkeen tavoitteena on tuottaa tietopaketti naisten työturvallisuudesta. Lisäksi selvitetään, miten työturvallisuuteen liittyviin asioihin sitoutumista voitaisiin parantaa maatilojen arjessa. Tässä yhteydessä raportoidaan kirjallisuustutkimuksen tuloksia sekä alustavia tuloksia empiirisestä aineistosta.

Maatalous on yksi neljästä vaarallisimmasta ammattialasta, jolla onnettomuuksia tapahtuu EU:n alueella 30 \% keskimääräistä tasoa enemmän. Maataloudessa, kalastuksessa ja porotaloudessa työskentelee Suomessa 30900 Melan vakuuttamaa naista. Heidän osuutensa on 35 \% kaikista Melan vakuuttamista henkilöistä. Viime vuosina julkaistussa tutkimuksessa (Rissanen toim. 2006) on havaittu tiettyjen vaaratekijöiden maatiloilla kohdistuvan etenkin naisiin. Maatiloilla työskentelevillä naisilla esiintyy miehiä enemmän pitkäaikaissairauksia, joiden määrä on lisääntynyt vuoteen 1992 verrattuna. Toinen huolestuttava tulos naisiin liittyen oli työn fyysinen raskaus. Työolosuhteiden erityisiä vaaroja aiheuttavat naisille myös eläinten kanssa työskentely, toistuvat työvaiheet, raskaat nostot, kantaminen sekä hankalat työasennot. Kaikkien psyykkisten oireiden esiintyvyys oli naisilla yleisempää kuin miehillä.

Naiseuteen liittyvät myös lisääntymisterveyden riskit. Himasen \& Seppälän (2006) tutkimuksen kyselyyn vastanneista lypsykarjatilojen naisista $77 \%$ arvioi saaneensa liian vähän raskauteen liittyvää terveystietoa; eniten tietoa kaivattiin maataloustyön fyysisen rasituksen vaikutuksista raskauteen. Naisten ja miesten työtehtävät maatiloilla ovat yleensä erilaiset. Naisten kokonaistyökuormitus saattaa olla huomattava, kun he vastaavat varsinaisten työtehtävien lisäksi kotitalouden töistä.

Nyt käynnissä olevassa tutkimuksessa haastatellut maitotiloilla työskentelevät naiset olivat keskimäärin 43-vuotiaita ja ammattinimikkeekseen he valitsivat yleisimmin maatalousyrittäjä. Yleisin syy alalla työskentelyyn oli viljelijän kanssa solmittu avioliitto. Maatilat olivat keskimääräistä suurempia, tutkimustiloilla oli keskimäärin 45 lehmää/tila. Laadullisen tutkimuksen menetelmin kerätty aineisto tuo esiin maatilalla työskentelevän naisen monitahoiset vastuut ja tilalla työskentelyn sairauden varjossa. Moni kertoi tekevänsä töitä myös sairaana. Havainnointiaineistossa ilmeni eläinten käsittelyn vaikutus naisen työturvallisuuteen ja hengityssuojainten vähäinen käyttö.

Maatilojen työympäristö on viime vuosien nopean rakennemuutoksen myötä muuttunut radikaalisti. Maatiloilla työskentelevät ovat vastuussa aiempaa suuremmista eläinmääristä ja peltoaloista. Myös tiloilla hyödynnettävät, työtä säästävät ja työoloja muuttavat tekniikat ovat lisääntyneet. Alan nopeaan muutostahtiin tarvittaisiin nyt kipeästi suvantovaihe. Yrityksen jatkuvassa laajentamispaineessa viime vuosina eläneet yrittäjät tarvitsisivat sellaista rauhaa, että heillä riittäisi aikaa paneutua oman jaksamisensa ja terveytensä vaalimiseen. Myös yhteiskunnan suhtautuminen alaan tulisi muuttua suopeammaksi, jotta maataloudessa työskentelevät itsekin arvostaisivat enemmän työtään, näkisivät sen tulevaisuuden positiivisena ja siten panostaisivat työolosuhteidensa parantamiseen.

Asiasanat: maatila, maatalousyrittäjä, emäntä, työturvallisuus, työhyvinvointi 


\section{Johdanto}

EU:n työterveyteen ja -turvallisuuteen liittyvän strategian mukaan maatalous on yksi neljästä vaarallisimmasta ammattialasta, jolla onnettomuuksia tapahtuu EU:n alueella $30 \%$ keskimääräistä tasoa enemmän. Myös Työturvallisuuslaitoksen koko suomalaiseen työssäkäyvään väestöön kohdistuvan "Työ ja terveys Suomessa 2006” -tutkimuksen tuloksista ilmenee maataloustyön vaarallisuus (Kauppinen et al. 2007). Eri ammattialojen vertailussa sekä tapaturmien esiintyminen että tapaturmavaaran kokeminen on yleisintä maataloustyön tekijöiden keskuudessa. Tapaturman uhriksi oli joutunut liki 30 \% maataloustyön tekijöistä vuoden aikana, kun keskimäärin työssä käyvistä tapaturma sattui 15 \%:lle miehistä ja 11 \%:lle naisista. Maatalouden tapaturmat ovat siis kaksi kertaa yleisempiä työssäkäyvien keskimääräiseen tasoon verrattuna. Kiire on yleisin tapaturmavaaran aiheuttaja maatiloilla. Myös kemiallisten altisteiden kuten liuottimien, pesuaineiden ja ärsyttävien aineiden osalta maatalous on yksi altistavimmista ammattialoista maassamme.

EU:n työterveyteen ja -turvallisuuteen liittyvässä strategiatekstissä painotetaan, että työolosuhteiden riskejä ja tapaturmien ehkäisyä tulisi tarkastella erityisesti naisten näkökulmasta (Comission of the European Communities 2002). Maataloudessa, kalastuksessa ja porotaloudessa työskentelee Suomessa 30900 Melan vakuuttamaa naista. Heidän osuutensa on 35 $\%$ kaikista vakuutetuista.

\section{Aineisto ja menetelmät}

MTT:ssä on meneillään "MYEL-vakuutettujen naisten työturvallisuus” eli Naisturva-hanke, joka sisältää kirjallisuustutkimuksen, havainnointi- ja haastatteluaineiston sekä kyselyn sidosryhmille. Empiirinen aineisto on kerätty laadullisen tutkimuksen menetelmin havainnoiden naisten työtä 10 maatilalla kesän 2007 aikana. Tutkimusaineisto kerättiin lypsykarjatiloilta, joista neljällä työskenneltiin parsinavetassa, neljällä pihattonavetassa ja kahdella robottilypsynavetassa. Tutkimustilat sijaitsevat Satakunnan, Pirkanmaan ja Uudenmaan maakuntien alueella. Tilakäyntiin sisältyi myös haastattelu työturvallisuudesta. Haastattelun aikana keskusteltiin seuraavista teemoista: taustatiedot haastateltavasta ja maatilasta, työt maatilalla, oma terveys, tapaturmat, suojainten käyttö, henkinen hyvinvointi, asema maatilalla sekä muutokset kahden vuoden aikana. Hankkeen tavoitteena on tuottaa tietopaketti naisten työturvallisuudesta maatiloilla. Lisäksi selvitetään, miten työturvallisuuteen liittyviin asioihin sitoutumista voitaisiin parantaa maatilojen arjessa. Tässä yhteydessä raportoidaan kirjallisuustutkimuksen tuloksia sekä alustavia tuloksia empiirisestä aineistosta.

\section{Tulokset; kirjallisuustutkimus ja empiirinen aineisto}

Viime vuosina julkaistussa tutkimuksessa (Rissanen toim. 2006) on havaittu tiettyjen vaaratekijöiden maatiloilla kohdistuvan etenkin naisiin. Maatiloilla työskentelevillä naisilla esiintyy miehiä enemmän pitkäaikaissairauksia, joiden määrä on lisääntynyt vuoteen 1992 verrattuna. Naiset myös arvioivat pitkäaikaissairauden haittaavan maataloustöitä useammin kuin miehet kaikissa ikäluokissa paitsi ryhmässä 55-64-vuotiaat. Myös Karttunen (2003) toteaa maidontuottajille tehdyn kyselyn tulosten pohjalta, että naisten työkyky oli kaikissa ikäluokissa keskimäärin alhaisempi kuin miesten ja lisäksi naisilla työkyvyn lasku ikääntymisen myötä oli voimakkaampaa kuin miehillä. Toinen huolestuttava tulos naisiin liittyen (Rissanen toim. 2006) oli työn fyysinen raskaus. Naiset arvioivat miehiä useammin työn fyysisen kuormituksen melko tai hyvin vaativaksi kaikissa ikäluokissa. Raskaita nostoja ja kantamista piti $31 \%$ naisvastaajista työympäristön haittaavuutena, kun samaa asiaa piti haittaavana $19 \%$ miehistä. Työolosuhteiden erityisiä vaaroja aiheuttavat naisille myös eläinten kanssa työskentely, toistuvat työvaiheet sekä hankalat työasennot (Rissanen toim. 2004). Susitaipaleen et al. (1994) kyselytutkimuksen mukaan käden ja käsivarren ihottumia esiintyi 16 \%:lla maatiloilla 
työskentelevillä naisilla. Työhön liittyviä riskitekijöitä olivat desinfiointiaineiden käyttö päivittäin, lehmien lypsäminen ja koneiden huoltotehtävät.

Naisille sattuu tapaturmia yleisimmin eläintenhoitotöissä (Hard et al. 1999, Virtanen et al. 2003). Karttunen et al. (2006) tulosten mukaan naisille sattuu miehiä enemmän tapaturmia työvaiheissa lypsy ja maidon käsittely, navetan puhdistus ja siivous.

Maataloudessa on kolme erityistä syövän riskitekijää ja karsinogeenista mekanismia: maatalouskemikaalit, eläinvirukset sekä immunologiset häiriöt, jotka johtuvat orgaanisista pölyistä, kasvinsuojeluaineista tms. (Kristenssen et al. 1996). Naiseuteen liittyvät myös lisääntymisterveyden riskit, kun raskaus ja synnytyksen jälkeinen aika luovat työolosuhteille omia vaatimuksia. Himanen \& Seppälä (2006) raportoivat, että 77 \% kyselyyn vastanneista lypsykarjatilojen naisista arvioi saaneensa liian vähän raskauteen liittyvää terveystietoa; eniten tietoa kaivattiin maataloustyön fyysisen rasituksen vaikutuksista raskauteen, kemikaaleista ja pölyaltistuksesta. Vastaajat arvioivat, että raskaus haittasi maatilan töiden tekemistä ja raskauden aikana vastaajilla esiintyi jalkojen väsymistä, selkäkipua ja työtä haittaavaa väsymistä. Engel et al. (2000) tulosten mukaan äidin altistuminen maatalouskemikaaleille kuten torjuntaaineille ja lannoitteille lisää lapsen raajavian riskiä.

Tutkimusraporteista ilmenee, että maatalouden työkalut ja laitteet eivät ole aina suunniteltu naisten käyttöä silmällä pitäen, jolloin niiden käyttö vaatii naisilta hankalia työasentoja ja aiheuttaa mahdollisen tapaturmavaaran (Reed et al. 1999, Dahlberg et al. 2004). Koneellistuminen, uusien tuotantoteknologioiden lisääntyminen ja tilojen koon kasvu ovat muuttaneet työolosuhteita huomattavasti viime vuosina. Tutkimustulosten pohjalta voidaan päätellä, että maatilayritysten työturvallisuuskoulutusta kannattaa suunnata nimenomaan maatiloilla työskenteleville naisille. Tällä tavalla on mahdollista kohentaa koko yrityksessä työskentelevien henkilöiden työturvallisuutta tässä ammatissa (Green 1999, Thompson ja Baker 2002).

Naisten ja miesten työtehtävät ovat perinteisesti eriytyneet suomalaisilla maatiloilla. Nainen pääsääntöisesti huolehtii kotitöistä, kun taas peltotyöt, metsätyöt ja koneiden huolto eivät niinkään kuulu naisen työtehtäviin (Sireni 2000, 2002). Naisten kokonaistyökuormitus saattaa olla huomattava, kun he vastaavat varsinaisten työtehtävien lisäksi kotitalouden töistä.

Naisturva-hankkeessa haastatellut maitotiloilla työskentelevät naiset olivat keskimäärin 43-vuotiaita ja ammattinimikkeeksi valittiin yleisimmin maatalousyrittäjä. Yleisin syy alalla työskentelyyn oli viljelijän kanssa solmittu avioliitto. Maatilat olivat keskimääräistä suurempia, lehmiä oli tässä aineistossa keskimäärin 45/tila. Laadullisen tutkimuksen menetelmin kerätty aineisto tuo esiin maatilalla työskentelevän naisen monitahoiset vastuut ja tilalla työskentelyn sairauden varjossa. Moni kertoi tekevänsä töitä myös sairaana. Havainnointiaineistossa ilmeni eläinten käsittelyn vaikutus naisen työturvallisuuteen ja henkityssuojainten vähäinen käyttö. Työn vaaroina mainittiin yleisesti väsymys ja kiire. Työn riskinä pidettiin sitä, että tiettyjen töiden osalta tila on hyvin riippuvainen toisen yrittäjän työpanoksesta. Yrittäjäpariskunnan yhteisen loman viettäminen vaati usein erityisiä järjestelyjä.

\section{Tulosten tarkastelu ja johtopäätökset}

EU:n näkökannoista ja painotuksista löytyy perusteita ja kannusteita nimenomaan naisten työturvallisuuden erilliseen tarkasteluun. Naisten työterveyden ongelmia maatiloilla ovat etenkin pitkäaikaissairaudet ja työn fyysinen kuormittavuus. Naisille sattuu tapaturmia yleisimmin eläintenhoitotöissä. Maatilalla käytettävät kemialliset aineet ja etenkin torjunta-aineet aiheuttavat selkeän työterveysriskin. Naiseuteen liittyvät myös lisääntymisterveyden riskit. Raskaus ja synnytyksen jälkeinen aika luovat työolosuhteille asetettaville vaatimuksille omat erityispiirteet. Maatiloilla käytettävät työvälineet saattavat olla lähinnä miesten käyttöä varten tai heidän näkökulmastaan suunniteltuja. Koneellistuminen, uusien tuotantoteknologioiden lisääntyminen ja tilojen koon kasvu on muuttanut työolosuhteita huomattavasti viime vuosina, 
joskin kehityskulussa on havaittavissa myös maatiloilla työskentelevien naisten määrän väheneminen.

Maatilojen työympäristö on viime vuosien nopean rakennemuutoksen myötä muuttunut radikaalisti. Maatiloilla työskentelevät ovat vastuussa aiempaa suuremmista eläinmääristä ja peltoaloista. Myös tiloilla hyödynnettävät, työtä säästävät ja työoloja muuttavat tekniikat ovat lisääntyneet. Tutkimuksen tilakäyntien jälkeen totean, että alan nopeaan muutostahtiin tarvittaisiin nyt kipeästi suvantovaihe. Yrityksen jatkuvassa laajentamispaineessa viime vuosina eläneet yrittäjät tarvitsisivat sellaista rauhaa, että heillä riittäisi aikaa paneutua oman jaksamisensa ja terveytensä vaalimiseen. Myös yhteiskunnan suhtautuminen alaan tulisi muuttua suopeammaksi, jotta maataloudessa työskentelevät itsekin arvostaisivat enemmän työtään, näkisivät sen tulevaisuuden positiivisena ja siten panostaisivat työolosuhteidensa parantamiseen.

Hanketta rahoittavat Maatalousyrittäjien eläkelaitos Mela, Maatalouskoneiden tutkimussäätiö ja Suomen Kulttuurirahasto.

\section{Kirjallisuus:}

Comission of the European Communities 2002. Communication from the Comission. Adapting to change in work and society: a new Community strategy on health and safety at work 2002-2006. COM(2002) 118 final. Brussels, 11.03.2002. 18 s. http://eur-lex.europa.eu/LexUriServ/site/en/com/2002/com2002 0118en01.pdf

Dahlberg R., Karlqvist L., Bildt C., Nykvist K. 2004. Do work technique and musculosketal symptoms differ between men and women performing the same type of work tasks? Applied Ergonomics 35 s.521-529.

Engel L. S., O'Meara E. S. \& Schwartz S. M. 2000. Maternal occupation in agriculture and risk of limb detects in Washington State 1980-1993. Scandinavian Journal of Work Environment and Health. Vol.26, no 3, s.193-198.

Green K. L. 1999. Farm Health and Safety: Rural Couples’Beliefs and Practices. Journal of Agricultural Safety and Health. Vol. 5 (1). s.85-96.

Hard D. L., Myers J. R., Snyder K. A. Casini V. J., Morton L. L., Cianfrocco R. Fields J. 1999. Identifying Work-related Fatalities in the Agricultural Production Sector Using Two National Occupational Fatality Surveillance System, 1990-1995. Journal of Agricultural Safety and Health. Vol.5(2) s.155-169.

Himanen S. \& Seppälä T. 2006. Raskaana lypsykarjatilan arjessa. Raskauteen liittyvät riskitekijät maatilan työssä. Opinnäytetyö. Hoitotyön koulutusohjelma, kätilötyön suuntautumisvaihtoehto, Pirkanmaan ammattikorkeakoulu. $66 \mathrm{~s}$.

Karttunen J. 2003. Maidontuottajan työ, työkyky ja vapaa-aika. Work, work ability and leisure of Finnish dairy farms. Työtehoseuran julkaisuja 389. $68 \mathrm{~s}$.

Karttunen J., Suutarinen J., Leppälä J., Louhelainen K. \& Tuure V.-M. 2006. Suhteellisesti vaarallisimmat maataloustyöt - Töiden organisoinnilla turvallisuutta ja tehokkuutta maitotiloille. Työtehoseuran julkaisuja 397. 75 s. 5 liitettä.

Kauppinen T., Hanhela R., Heikkilä P., Kasvio A., Lehtinen S., Lindström K., Toikkanen J., Tossavainen A. toim. 2007. Työ ja terveys Suomessa 2006. Työterveyslaitos, Helsinki. 462 s.

Kristenssen P., Andersen A., Irgens L. M. Laake P. \& Bye A. S. 1996. Incidence and risk factors of cancer among men and women in Norvegian agriculture. Scandinavian Journal of Work, Environment \& Health. Vol. 22. s.14-26.

Reed D.B., Westneat S.C., Browning S.R. \& Skarke L. 1999. The hidden Work of the Farm Homemaker. Journal of Agricultural Safety and Health. Vol. 5(3), s. 317-327.

Rissanen P. (toim.) 2006. Työterveys ja maatalous Suomessa 2004. Maatalousympäristön terveydelliset riskit ja niihin vaikuttaminen. Kuopio:Työterveyslaitos. $101 \mathrm{~s}$.

Sireni M. 2000. Hyvät pientilan emännät. Teoksessa: Högbacka R. \& Trast T. (toim.) 2000. Monessa mukana. Näkymiä naisen työhön ja elämään maaseudulla. Maaseutupolitiikan yhteistyöryhmä, Vantaa. 152 s.

Sireni M. 2002. Tilansa tekijät. Tutkimus emännyydestä ja maatilasta naisen paikkana. Actors on the farm: Research on the Role of a Matron and on the Farm as a Place for a Woman. Joensuun yliopiston yhteiskuntatieteellisiä julkaisuja n:o 56.287 s. 5 liitettä. Joensuun yliopisto, Joensuu.

Susitaival P., Husman L. Hosrmanheimo M., Notkola V. \& Husman K. 1994. Prevalence of hand dermatoces among Finnish farmers. Scandinavian Journal of Work \& environment \& Health. Vol. 20. s. 206-212.

Thompson G. W. \& Baker D.E. 2002. Making Safety a Priority with Farm Women. Agricultural Safety and Health Detection, Prevention and Intervention Conference, Columbus, the Ohio State University \& the Ohio Department of Health, proceeding

Virtanen S. V., Notkola V., Luukkonen R. Eskola E. \& Kurppa K. 2003. Work Injuries Among Finnish Farmers: A National Register Linkage Study 1996-1997. American Journal of Industrial Medicine. Vol. 43. s.314-325. 